\title{
MICROCLIMATIC CHANGES CAUSED BY DIFFERENT PLASTIC COVERINGS IN GREENHOUSES CULTIVATED WITH CHERRY TOMATO IN SOUTHERN BRAZIL
}

\author{
ESTER HOLCMAN ${ }^{1}$, PAULO C. SENTELHAS ${ }^{1}$, SIMONE DA C. MELLO ${ }^{2}$ \\ ${ }^{1}$ University of São Paulo, Agricultural College "Luiz de Queiroz" (USP/ESALQ), Department of \\ Biosystems Engineering, Piracicaba/SP, Brazil \\ ${ }^{2}$ USP/ESALQ, Department of Crop Science, Piracicaba, SP, Brazil \\ esterholcman@yahoo.com.br, pcsentel.esalq@usp.br,cmello@usp.br
}

Received July 2014 - Accepted October 2014

\begin{abstract}
In regions with intense solar radiation it is common the use of aluminated covers in greenhouses, with the aim of reducing the inside temperature. However, the use of these covers reduces photosynthetic active radiation (PAR) transmitted into the greenhouse. The objective of the present study was to evaluate the influence of different covers on microclimate in greenhouses cultivated with cherry tomato during three growing seasons. The environment I was covered with plastic film anti-UV and with thermo-reflective screen $(40 \%)$ disposed internally. The environment II was covered with diffusive plastic film (55\%). The transmitted solar radiation to the interior of covered environments was, on average, $5.5 \mathrm{MJ} \mathrm{m}^{-2}$ day $^{-1}$ in the environment I and $8.2 \mathrm{MJ} \mathrm{m}^{-2}$ day $^{-1}$ in environment II. The air temperature in environment II was, on average, $1^{\circ} \mathrm{C}$ higher than external conditions. The highest difference for the relative humidity (RH) was also observed between environment II and the outside conditions, with $10.7 \%$ for the minimum RH during the first growing period. Considering all growing periods, the diffusive plastic film provided higher solar energy availability inside the greenhouse than the plastic film with thermo-reflective screen, without causing major changes in air temperature and relative humidity, and promoting greater productivity of tomato grown under this environment for the three periods evaluated. Keywords: greenhouses; plastic covers; microclimate.
\end{abstract}

RESUMO:ALTERAÇÕES MICROCLIMÁTICAS PROVOCADAS POR DIFERENTES COBERTURAS PLÁSTICAS EM AMBIENTE PROTEGIDO CULTIVADO COM TOMATE TIPO CEREJA NO SUDESTE DO BRASIL

Em regiões de intensa radiação solar é comum o uso de malhas aluminizadas em cultivos protegidos, com o intuito de reduzir a temperatura no interior de estufas plásticas. Porém, o uso dessas malhas provoca diminuição da radiação fotossinteticamente ativa (RFA) transmitida ao interior do ambiente protegido. O presente estudo teve por objetivo avaliar a influência de diferentes coberturas plásticas no microclima de ambientes protegidos, ao longo de três períodos de cultivo com tomate cereja. $\mathrm{O}$ ambiente I foi coberto com filme plástico anti-UV e com uma malha termorefletora $(40 \%)$ disposta internamente. O ambiente II foi coberto com filme plástico difusor $(55 \%)$. A radiação solar transmitida ao interior dos ambientes protegidos foi, em média, de $5,5 \mathrm{MJ} \mathrm{m}^{-2}$ $\mathrm{dia}^{-1}$ no ambiente I e $8,2 \mathrm{MJ} \mathrm{m}^{-2} \mathrm{dia}^{-1}$ no ambiente II. A temperatura do ar no ambiente II foi, em média, $1^{\circ} \mathrm{C}$ superior ao ambiente externo. As maiores diferenças para a umidade relativa do ar também foram encontradas entre o ambiente II e o externo, chegando a 10,7\% para a UR mínima, no primeiro período de cultivo. Considerando-se todos os ciclos de cultivo, o plástico difusor foi o que proporcionou a maior disponibilidade de energia no interior do ambiente protegido, sem causar, no entanto, grandes alterações na temperatura e na umidade relativa do ar, e promovendo uma maior produtividade do tomate cultivado sob este ambiente, nos três períodos avaliados.

Palavras-chave: ambiente protegido; coberturas plásticas; microclima. 


\section{INTRODUCTION}

The type of material used as covering in greenhouses has important role in defining the microclimate of them by changing the solar radiation flux density inside greenhouse, in accordance with the change of its transmissivity (Steidle Neto et al., 2006; Finch et al., 2004). Incoming solar radiation within greenhouses is always lower than that in an open sky surface, due to the processes of reflection and absorption by the plastic coverings (Galvani, 2001; Guiselini, 2002). According to Sentelhas et al. (1999) and Serrano et al. (2001), the solar radiation transmissivity in greenhouses depends on the type, thickness, dust deposition, water condensation and level of degradation of the plastic used, as well as the orientation and shape of the coverage, the time of year and other structures, like bows, fence posts, irrigation canals, screens, etc. The reduction of solar radiation transmissivity due to the cover ranges from 5 to $40 \%$ (Serrano et al., 2001).

The characterization of greenhouse covers transmissivity is important since it affects other components of the energy balance, as the sensible and latent heat fluxes, as well as the photosynthetic process (Pezzopane et al., 2004). Reduction of solar radiation, as a way to avoid high temperatures, implies directly in reducing photosynthetic active radiation (PAR) transmitted into the greenhouse. Therefore, it is important to have appropriate levels of shading, in order to avoid negative effects on plants (Faria Junior et al., 2000; Guiselini et al., 2007). So, the choice of the cover material of greenhouses is essential for optimizing crop production.

According to Buriol et al. (2000), air temperature is mainly influenced by solar radiation flux density and wind speed, which depend on the area, location and management of the greenhouse (wall cover). While inside solar radiation affects the air temperature, wind speed determines the rate of sensible heat exchange between inside and outside of the greenhouse. The reduction of greenhouse air temperature is one of the main objectives in tropical regions, where high temperatures are commonly observed. To this end, shading screens are most used option (Serrano et al., 2001; Pandorfi, 2006).

Currently, new cover materials have been developed with the aim of promoting greater dispersion of solar radiation transmitted into the greenhouse. A plastic film is called as a diffusive when has such ability. A film is considered diffusive when its turbidity is equal to or greater than $30 \%$ for thicknesses between 70 and $150 \mu \mathrm{m}$ and $35 \%$ for thicknesses equal to or greater than $150 \mu \mathrm{m}$. Depending on the composition of the diffusive plastic, the proportion of PAR that is transmitted into the greenhouse can be equal or even greater than those of a transparent film with the same characteristics (Serrano et al., 2001). Diffusive films are composed by microscopic particles that spread the light in all directions. During sunny days, greenhouses covered with diffusive plastic film can have three to four times more diffuse radiation than outside (Baille et al., 2003). Thus, inside greenhouses, the shadow projection becomes less sharp than outside (Castilla, 2005).

Considering that the greenhouse cover has a major influence on the microclimate for the crops, the objective of this study was to evaluate and compare the effects of different types of covers, diffusive plastic film and plastic film anti-UV associated with thermo-reflective screen on temperature, relative humidity and solar radiation, and, consequently, on cherry tomato productivity.

\section{MATERIALS AND METHODS}

The field experiments were carried out in the experimental area of the Department of Crop Science, at the Agricultural College "Luiz de Queiroz", University of São Paulo (ESALQ/ USP), in Piracicaba, State of São Paulo, Brazil, located in the following geographic coordinates: latitude of $22^{\circ} 42$ ' $40^{\prime \prime} \mathrm{S}$, longitude of $47^{\circ} 37^{\prime} 30^{\prime \prime} \mathrm{W}$ and altitude of 546 m.a.s.1. In accordance with the Köppen classification, the climate of the region is Cwa, which means tropical humid with dry winter. Table 1 presents the climatic data of Piracicaba, for the period between $1997-2013$.

The experiments were conducted in a greenhouse with the following dimensions: 50-m length, 7-m width, 4-m height and oriented from NE to SW. This environment was subdivided in two equal parts, isolated by a transparent polyethylene of low density (LDPE) plastic film, of $0.15 \mathrm{~mm}$ of thickness. These two environments were covered with different materials: one was covered with an anti-UV plastic film associated with the thermo-reflective screen (with $40 \%$ of shading mesh), installed internally at the ceiling height (environment I = EI); and another environment (environment II = EII) with a diffusive plastic film with $55 \%$ of diffusive capacity (Figure 1). The greenhouse's walls were covered with black screens (with $50 \%$ of shading mesh), allowing lateral ventilation in both environments. Both the environments were cultivated with cherry tomato (Solanum lycopersicum var. cerasiforme).

The physical analysis of the environments was done by micrometeorological measurements with automatic sensors. These sensors were installed in the center of each environment. The position of each sensor in the interior of the environments is shown in Figure 1. The sensors were connected to a datalogger CR10x model (Campbell Sci.), which continuously recorded air temperature - T and relative humidity - RH (model HMP35, Vaisala), global solar radiation - SR (model CM3, Kipp and Zonen), net radiation - Rn (NR-lite model, Kipp and Zonen) and photosynthetic active radiation - PAR (model LI190SB, Licor quantum sensor). All these sensors were previously calibrated 
Table 1 - Monthly climatic data for Piracicaba, SP, Brazil, for the period between 1997 and 2013.

\begin{tabular}{|c|c|c|c|c|c|c|c|c|c|c|}
\hline & $\mathrm{T}$ avg & $\mathrm{T} \max$ & $\mathrm{T} \min$ & RH avg & $\mathrm{RH} \max$ & RH min & WS & WS max & \multirow{2}{*}{$\frac{\mathrm{R}}{\mathrm{mm}}$} & \multirow{2}{*}{$\frac{\mathrm{SR}}{\mathrm{MJ} \mathrm{m}^{-2}}$} \\
\hline & \multicolumn{3}{|c|}{${ }^{\circ} \mathrm{C}$} & \multicolumn{3}{|c|}{$\%$} & \multicolumn{2}{|c|}{$\mathrm{m} \mathrm{s}^{-1}$} & & \\
\hline Jan & 23.6 & 29.7 & 19.6 & 89.1 & 99.7 & 62.2 & 1.1 & 8.5 & 256.5 & 224.4 \\
\hline Feb & 24.2 & 30.8 & 19.6 & 87.0 & 99.8 & 56.7 & 1.0 & 8.2 & 148.6 & 207.9 \\
\hline Mar & 23.7 & 30.3 & 18.9 & 85.5 & 99.5 & 56.3 & 1.1 & 8.0 & 137.4 & 215.5 \\
\hline Apr & 22.1 & 28.9 & 16.7 & 84.3 & 99.7 & 53.4 & 1.0 & 7.0 & 65.8 & 166.1 \\
\hline May & 18.7 & 25.7 & 12.9 & 84.8 & 99.8 & 52.8 & 1.0 & 6.8 & 58.7 & 134.3 \\
\hline Jun & 17.8 & 25.3 & 11.6 & 84.8 & 99.8 & 52.2 & 1.0 & 6.2 & 48.9 & 113.5 \\
\hline Jul & 17.8 & 25.6 & 11.2 & 81.1 & 99.3 & 47.9 & 1.1 & 6.7 & 36.8 & 126.5 \\
\hline Aug & 19.4 & 27.5 & 12.0 & 73.8 & 98.7 & 39.9 & 1.3 & 7.4 & 22.7 & 149.1 \\
\hline Sep & 21.1 & 28.6 & 14.5 & 74.8 & 97.7 & 44.8 & 1.5 & 8.6 & 53.9 & 157.4 \\
\hline Oct & 22.7 & 29.7 & 16.9 & 79.2 & 98.6 & 49.5 & 1.6 & 8.9 & 101.7 & 189.5 \\
\hline Nov & 23.1 & 29.8 & 17.7 & 81.2 & 98.9 & 52.0 & 1.6 & 9.2 & 127.4 & 195.1 \\
\hline Dec & 23.9 & 30.3 & 19.2 & 85.3 & 99.4 & 57.1 & 1.3 & 8.9 & 183.8 & 200.3 \\
\hline Total & - & - & - & - & - & - & - & - & 1242,2 & - \\
\hline Average & 21.5 & 28.5 & 15.9 & 82.6 & 99.2 & 52.1 & 1.2 & 7.9 & - & 173.3 \\
\hline Maximum & 24.2 & 30.8 & 19.6 & 89.1 & 99.8 & 62.2 & 1.6 & 9.2 & 256.5 & 224.4 \\
\hline Minimum & 17.8 & 25.3 & 11.2 & 73.8 & 97.7 & 39.9 & 1,0 & 6.2 & 22.7 & 113.5 \\
\hline
\end{tabular}

Tavg = average air temperature; Tmax $=$ maximum air temperature; Tmin = minimum air temperature; RHavg $=$ average relative humidity; $\mathrm{RHmax}=$ maximum relative humidity; $\mathrm{RHmin}=$ minimum relative humidity; $\mathrm{WS}=$ average wind speed; $\mathrm{WSmax}=$ maximum wind speed; $\mathrm{R}=$ rainfall; $\mathrm{SR}=$ incoming solar radiation.

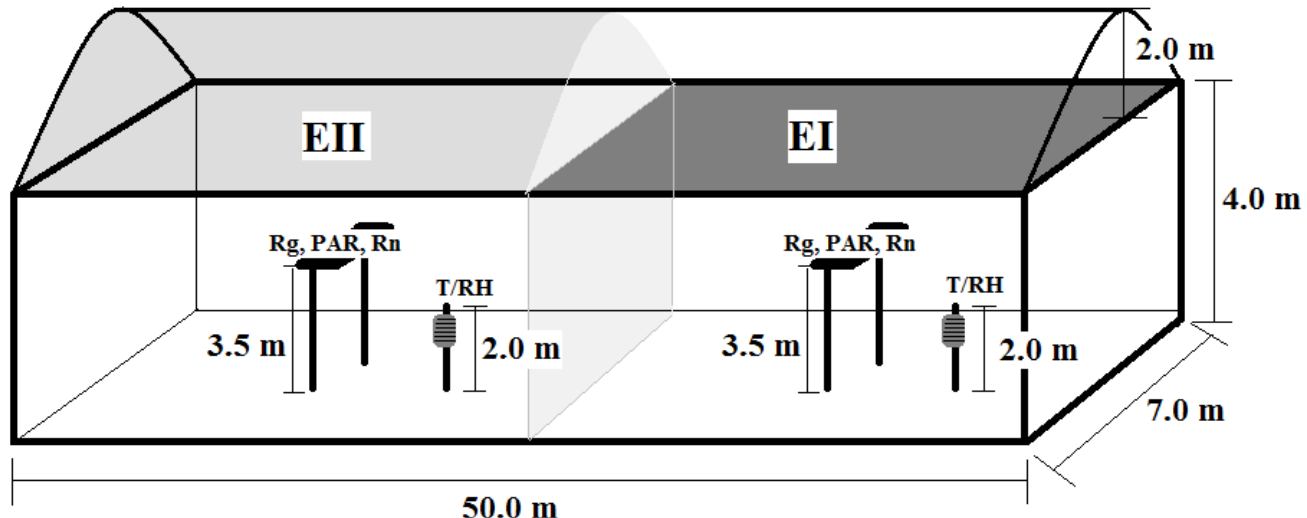

Figure 1 - Schematic representation of greenhouse with the following environments: Environment I $(\mathrm{EI})=$ polyethylene anti-UV + thermo-reflective screen and Environment II (EII) = diffusive plastic screen; and the meteorological sensors installed in the center of each one.

and adapted for measurements under plastic covers. The data were recorded every second and averages were computed every 15 minutes. Micrometeorological data were collected during the following growing seasons: from $28 / 08$ to 30/09/08 ( $1^{\text {st }}$ period); from $24 / 06$ to $20 / 09 / 09$ ( $2^{\text {nd }}$ period $)$; and from $12 / 09$ to $06 / 12 / 10$ ( $3^{\text {rd }}$ period). These data were compared with the outside conditions, obtained from an automatic weather station located at $300 \mathrm{~m}$ from the experimental area. For each period separately, the meteorological averages were compared by Kruskal Wallis test (Assistat Software) and the results of tomato productivity were submitted to analysis of variance and comparison of averages (Tukey - 5\%), with the GLM procedures of SAS (Statistical Analysis Software).

\section{RESULTS AND DISCUSSION}

Table 2 presents the values of solar radiation measured in each studied environment. It was observed that, in the EII (diffusive plastic), SR, PAR and Rn were greater than those obtained in the EI (plastic anti-UV + thermo-reflective screen). This fact occurred in all periods, due to plastic anti-UV to be associated with the shading screen, resulting in a significant reduction of the incoming solar radiation in EI. The diffusive plastic (EII) allowed greater incidence of solar radiation inside the greenhouse or transmitted SR (tSR).

According to the Table 2, a reduction in the solar radiation transmissivity by the coverings occurred over the three 
Table 2 - Incoming solar radiation (SR), photosynthetically active radiation (PAR) and net radiation (Rn), and their respective transmissivity (tSR, tPAR and $t R n)$ in each studied environment: Environment I $(E I)=$ polyethylene anti-UV + thermo-reflective screen; Environment II $($ EII $)=$ diffusive plastic screen; and Outside conditions $(\mathrm{E}$ out $)=$ meteorological station.

\begin{tabular}{|c|c|c|c|c|c|}
\hline \multirow{2}{*}{ Period } & \multicolumn{3}{|c|}{$\mathrm{SR}\left(\mathrm{MJ} \mathrm{m}^{-2} \mathrm{~d}^{-1}\right)$} & \multicolumn{2}{|c|}{$\operatorname{tSR}(\%)$} \\
\hline & EI & EII & E out & EI & EII \\
\hline $1^{\text {st }}$ & $6.6 \mathrm{a}$ & $10.7 \mathrm{ab}$ & $17.0 \mathrm{~b}$ & 39.1 & 62.6 \\
\hline $2^{\text {nd }}$ & $4.3 \mathrm{a}$ & $6.0 \mathrm{a}$ & $13.7 \mathrm{~b}$ & 31.7 & 43.8 \\
\hline $3^{\text {rd }}$ & $5.7 \mathrm{a}$ & $8.0 \mathrm{~b}$ & $20.4 \mathrm{c}$ & 27.8 & 39.1 \\
\hline \multirow{2}{*}{ Period } & \multicolumn{3}{|c|}{$\operatorname{PAR}\left(\mathrm{MJ} \mathrm{m}^{-2} \mathrm{~d}^{-1}\right)$} & \multicolumn{2}{|c|}{$\operatorname{tPAR}(\%)$} \\
\hline & EI & EII & E out & EI & EII \\
\hline $1^{\text {st }}$ & $2.0 \mathrm{a}$ & $4.0 \mathrm{ab}$ & $6.2 \mathrm{~b}$ & 32.3 & 64.5 \\
\hline $2^{\text {nd }}$ & $1.5 \mathrm{a}$ & $2.9 \mathrm{~b}$ & $5.2 \mathrm{c}$ & 28.8 & 55.8 \\
\hline $3^{\mathrm{rd}}$ & $2.6 \mathrm{a}$ & $5.0 \mathrm{~b}$ & $9.6 \mathrm{c}$ & 27.4 & 51.7 \\
\hline \multirow{2}{*}{ Period } & \multicolumn{3}{|c|}{$\mathrm{Rn}\left(\mathrm{MJ} \mathrm{m}^{-2} \mathrm{~d}^{-1}\right)$} & \multicolumn{2}{|c|}{$\operatorname{tRn}(\%)$} \\
\hline & EI & EII & E out & EI & EII \\
\hline $1^{\text {st }}$ & $4.8 \mathrm{a}$ & $7.7 \mathrm{~b}$ & $7.8 \mathrm{~b}$ & 61.5 & 98.7 \\
\hline $2^{\text {nd }}$ & $3.4 \mathrm{a}$ & $5.9 \mathrm{~b}$ & $5.3 \mathrm{~b}$ & 64.2 & 111.3 \\
\hline $3^{\text {rd }}$ & $5.7 \mathrm{a}$ & $9.3 \mathrm{~b}$ & $9.6 \mathrm{~b}$ & 59.0 & 97.0 \\
\hline
\end{tabular}

periods. This effect was observed from $1^{\text {st }}$ to $2^{\text {nd }}$ period $(18.9 \%$ and $30.0 \%$ for EI and EII, respectively). From $1^{\text {st }}$ to $3^{\text {rd }}$ period this reduction was even higher, about $28.9 \%$ for EI and $37.5 \%$ for EII. This process occurred as a result of several factors. In the first instance, the $1^{\text {st }}$ period was conducted during the spring and early summer, while the $2^{\text {nd }}$ period was conducted in the period of the autumn and winter and the $3^{\text {rd }}$ period, during winter and spring. Therefore, the season of the year influenced the transmissivity of the covers, which was also reported by Galvani (2001), who observed transmission of $70.8 \%$ in the winter and $75.0 \%$ in the summer for a transparent plastic film. The other factors to be considered are the age of the plastic films and the deposition of dust on them, which also causes reduction in their transmittance. Frisina and Escobedo (1999) observed a reduction of $20.4 \%$ in the transmittance of a low density polyethylene plastic film after six months of use. Pandorfi (2006) also noted a reduction of the plastic transmittance in greenhouses between two growing seasons, of about $4 \%$ in the greenhouse with the thermo-reflective screen installed internally.

In relation to the outside environment, the Rn inside EII (diffusive plastic) was close to that observed externally (Table 2). This effect was due to the ability of the diffusive plastic to partially block the long wave radiation emitted by the surface and it was more pronounced along the $2^{\text {nd }}$ period, when the internal Rn, on average, was higher than external Rn. During the day, the Rn in EI and EII was always similar, but smaller than the values observed outside. However, at night (Figure 2), the external Rn was more negative than under the two covers assessed, showing that the "greenhouse effect" was effective.
Therefore, when evaluating the daily averages of $\mathrm{Rn}$, the outside values became smaller, because the higher magnitudes of the nighttime balance (more negative). Agreeing with the values observed in this experiment, Galvani (2001) reported that on days with low solar radiation (overcast), solar radiation balance are normally higher inside the greenhouses, because the effective long-wave emission is reduced, resulting in less negative Rn. Thus the daily radiation balance is, in general, greater inside greenhouses. However, in the present study, this effect was observed not only in the cloudy sky days, but also in the partly cloudy and clear sky days.

The solar energy availability in EII (diffusive plastic) was higher than in EI (plastic anti-UV + thermo-reflective screen). Observing Figure 3 , it is possible to see that, in the $1^{\text {st }}$ period PAR was about $27 \%$ higher in EII than in EI. The PAR/SR in EII was very similar to outside greenhouse, in the first period. In the $2^{\text {nd }}$ and $3^{\text {rd }}$ periods the conditions were different, having an increase of PAR inside greenhouse environments in relation to the outside.

Guiselini (2002) and Sentelhas et al. (1997) also observed null effect caused by thermo-reflective screen in PAR/SR. These results differ substantially from those found by Pandorfi (2006) and Kittas et al. (1999), in which the use of thermo-reflective screen also decreased this ratio. From $1^{\text {st }}$ to $3^{\text {rd }}$ period there was an increase of $63 \%$ in the PAR/SR proportion in the interior of EII, which is an extremely significant value. The differences mentioned above were caused mainly by seasons, since the availability of solar radiation in the $3^{\text {rd }}$ period was higher than the previous periods, which can be seen in Figure 4. 

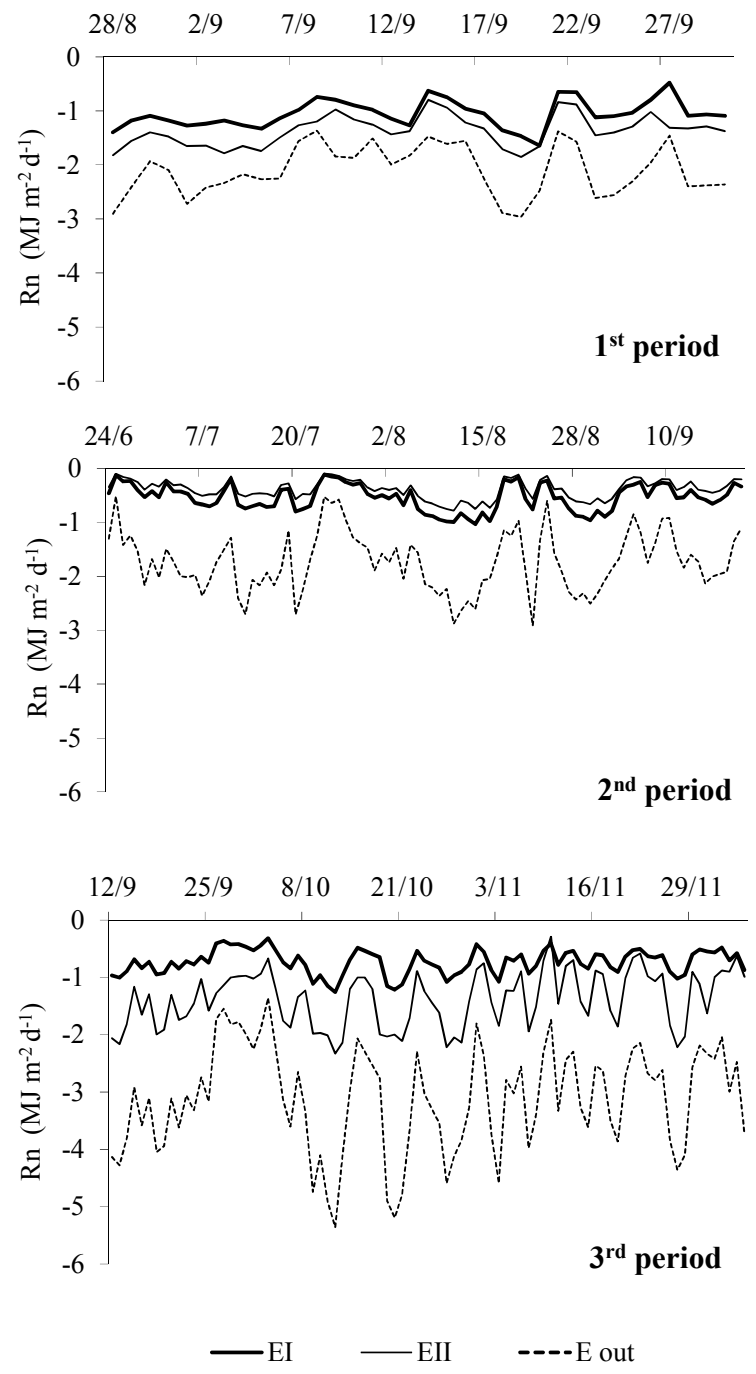

Figure 2 - Nocturnal net radiation (Rn) over the three evaluated periods in the Environment I $(\mathrm{EI})=$ polyethylene anti-UV + thermoreflective screen, Environment II (EII) = diffusive plastic screen, and outside (E out).

Table 3 presents the relationship between the daily values of weather variables SR, PAR and Rn measured inside the greenhouses and outside during the three evaluated periods. The determination coefficients were very high in both environments in the majority of the cases $\left(r^{2}>0.97\right)$, except for EI during the $2^{\text {nd }}$ period for SR and PAR.

The angular coefficients observed in Table 3 are very similar to the average transmissivity shown in Table 2, with the EII presenting a solar radiation transmissivity higher than EI. These coefficients also showed that there was a reduction of transmissivity from one period to another, as mentioned previously.

Typically, inside the greenhouses the air temperature is higher than outside (Galvani, 2001; Guiselini, 2002; Guiselini and Sentelhas, 2004; Guiselini et al., 2007). This
Table 3 - Relationship between incoming solar radiation (SR), photosynthetically active radiation (PAR), net radiation ( $\mathrm{Rn}$ ) observed inside Environment I (EI) = polyethylene anti-UV + thermo-reflective screen; Environment II (EII) = diffusive plastic screen; and outside (E out) the greenhouses.

\begin{tabular}{|c|c|c|c|}
\hline \multirow{2}{*}{ Period } & \multirow{2}{*}{ Linear regression } & \multicolumn{2}{|c|}{ Coefficients } \\
\hline & & $\mathrm{b}$ & $\mathrm{R}^{2}$ \\
\hline \multicolumn{4}{|c|}{ SR } \\
\hline \multirow{2}{*}{$1^{\text {st }}$} & EI $x$ E out & 0.4216 & 0.9902 \\
\hline & EII $x$ E out & 0.6714 & 0.9760 \\
\hline \multirow{2}{*}{$2^{\text {nd }}$} & EI $x \mathrm{E}$ out & 0.3331 & 0.7458 \\
\hline & EII $x$ E out & 0.4356 & 0.9753 \\
\hline \multirow{2}{*}{$3^{\text {rd }}$} & EI $x$ E out & 0.2764 & 0.9961 \\
\hline & EII $x$ E out & 0.3976 & 0.9701 \\
\hline \multicolumn{4}{|c|}{ PAR } \\
\hline \multirow{2}{*}{$1^{\text {st }}$} & EI $x$ E out & 0.2173 & 0.9799 \\
\hline & EII $x$ E out & 0.3466 & 0.9719 \\
\hline \multirow{2}{*}{$2^{\text {nd }}$} & EI $x$ E out & 0.2857 & 0.6912 \\
\hline & EII $x$ E out & 0.5514 & 0.9479 \\
\hline \multirow{2}{*}{$3^{\mathrm{rd}}$} & EI $x$ E out & 0.2721 & 0.9710 \\
\hline & EII $x$ E out & 0.5100 & 0.9386 \\
\hline \multicolumn{4}{|c|}{$\mathrm{Rn}$} \\
\hline \multirow{2}{*}{$1^{\text {st }}$} & EI x E out & 0.5874 & 0.9334 \\
\hline & EII $x$ E out & 10.110 & 0.9634 \\
\hline \multirow{2}{*}{$2^{\text {nd }}$} & EI x E out & 0.6075 & 0.9226 \\
\hline & EII $x$ E out & 10.585 & 0.9416 \\
\hline \multirow{2}{*}{$3^{\text {rd }}$} & EI $x$ E out & 0.5632 & 0.9885 \\
\hline & EII $x$ E out & 0.9224 & 0.9844 \\
\hline
\end{tabular}

was also observed in the present study (Table 4); however the temperature differences, for maximum, minimum and averages values, were very small which is probably associated to the ceiling height and use of screens in the walls, favoring the air circulation, resulting in less accumulation of sensible heat nearby the sensors. Caliman et al. (2005) also reported similar results in terms of daily minimum and average temperatures between plastic greenhouses and outside conditions. In the present study, the EII (diffusive plastic) presented the highest average value, since it allowed the greatest transmissivity of solar radiation into the greenhouse. So, in this environment, more solar energy was converted into sensible heat flux, resulting in higher average temperatures, about $1.0^{\circ}, 0.4^{\circ}$ and $1.5^{\circ} \mathrm{C}$ higher than outside respectively for the $1^{\text {st }}, 2^{\text {nd }}$ and $3^{\text {rd }}$ periods evaluated. Only in the $3^{\text {rd }}$ period the EI presented a bit more pronounced difference in temperature, which was a function of the plastic age and deposition of dust on it. It means that the plastic absorbed a larger portion of intercepted solar radiation, transferring the captured energy into the greenhouse as long wave and heat.

The largest differences between greenhouses and outside occurred for maximum temperature (Table 4). This usually occurs due to the plastic covers act as a physical barrier to the 

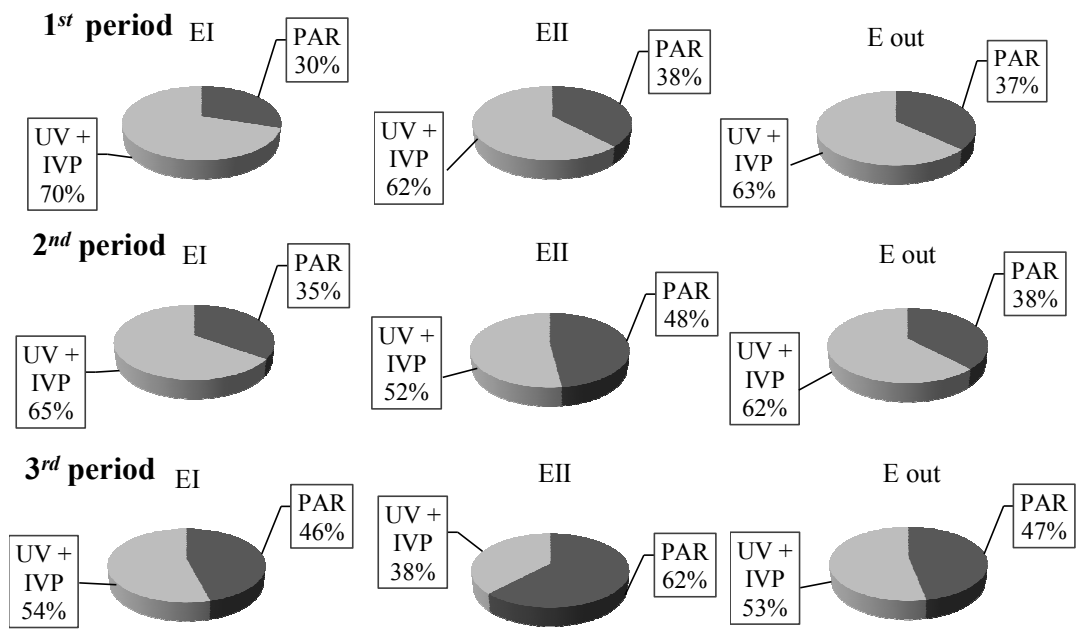

Figure 3 - Partition of global solar radiation (SR) in photosynthetic active radiation (PAR), ultraviolet radiation and near-infrared (UV + IVP) in the Environment I $(\mathrm{EI})=$ polyethylene anti-UV + thermo-reflective screen, Environment II (EII) = diffusive plastic screen, and outside conditions (E out) for the three periods.
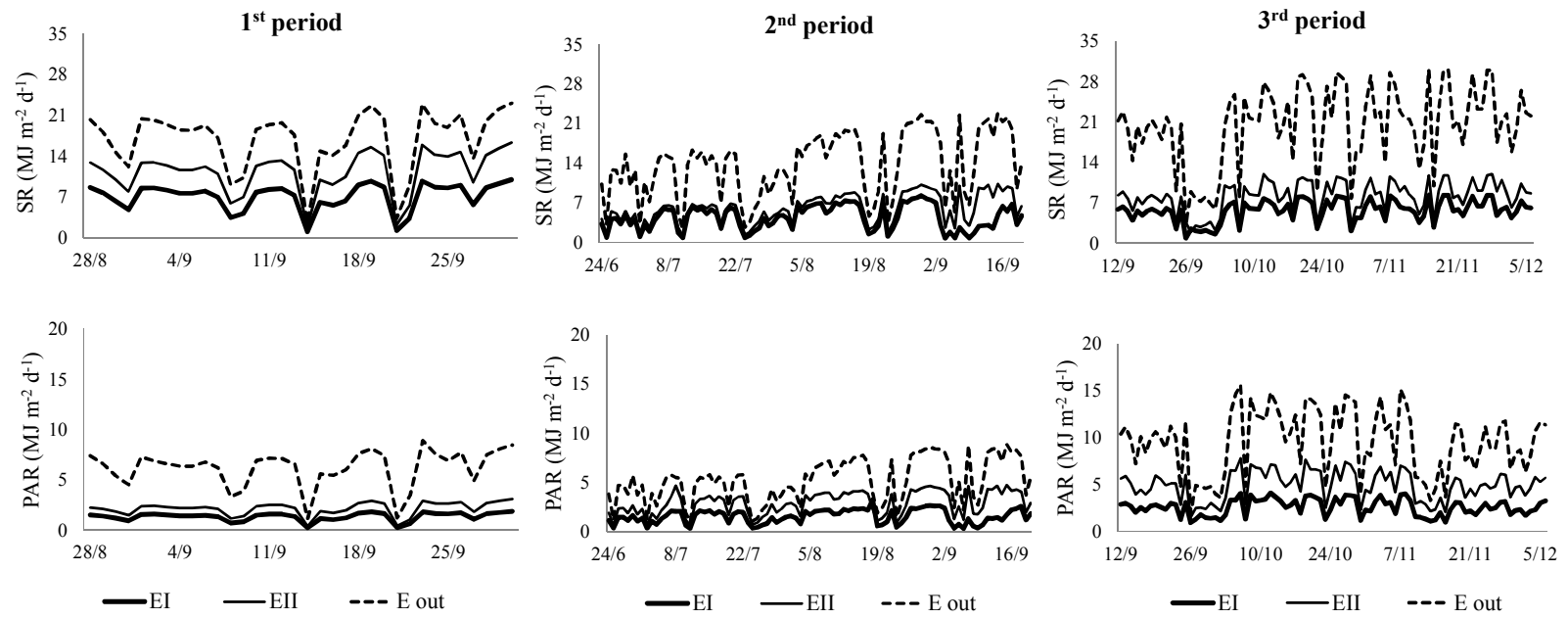

Figure 4 - Availability of global solar radiation (SR) and photosynthetic active radiation (PAR) during the three evaluated periods in: Environment $\mathrm{I}(\mathrm{EI})=$ polyethylene anti-UV + thermo-reflective screen, Environment II $(\mathrm{EII})=$ diffusive plastic screen, and outside conditions $(\mathrm{E}$ out $)$.

air convection, "imprison" the sensible heat flux inside. Note that the largest differences in relation to outside condition occurred for the maximum temperature in the EII (diffusive plastic), with $1.5^{\circ}, 1.2^{\circ}$ and $1.8^{\circ} \mathrm{C}$ above external temperature, respectively, in the $1^{\text {st }}, 2^{\text {nd }}$ and $3^{\text {rd }}$ period. This increase, as mentioned before, depends on several factors, which combined can result in very extreme conditions, as observed in the study of Shirahigi (2009) where inside average temperature was $8.5^{\circ} \mathrm{C}$ higher than outside.

The average values of $\mathrm{RH}$ in both greenhouses were slightly lower than those found outside, on average, $1.9 \%$ and $4.4 \%$ in EI and EII, respectively. Similar results were observed by Pandorfi (2006), who registered RH differences of $2.5 \%$ to $3.6 \%$ between greenhouses and external conditions, while Rocha (2007) observed differences of 7.5\%. Comparing the two greenhouse environments, the diffusive plastic (EII) promoted the lower RH values over the evaluated periods for having higher air temperature.

In all environments average maximum $\mathrm{RH}$ was close to $100 \%$. For average minimum RH, responsible for the main differences between the two environments, the same trend was observed, i.e., outside RH was always higher than that registered inside the greenhouses. These results were expected, since the inside temperatures have always been slightly higher than the values obtained outside. Pandorfi (2006) also found major differences between the outside and inside greenhouses 
Table 4 - Air temperature $\left(\mathrm{T},{ }^{\circ} \mathrm{C}\right)$ and relative humidity $(\mathrm{RH}, \%)$ observed inside Environment I $(\mathrm{EI})=$ polyethylene anti-UV + thermo-reflective screen; Environment II (EII) = diffusive plastic screen; and outside (E out) the greenhouses.

\begin{tabular}{|c|c|c|c|c|c|c|c|c|c|}
\hline \multirow{3}{*}{ Variable } & \multicolumn{9}{|c|}{ Periods } \\
\hline & \multicolumn{3}{|c|}{$1^{\text {st }}$} & \multicolumn{3}{|c|}{$2^{\text {nd }}$} & \multicolumn{3}{|c|}{$3^{\mathrm{rd}}$} \\
\hline & EI & EII & E out & EI & EII & E out & EI & EII & E out \\
\hline Average $T$ & $19.3 \mathrm{a}$ & $20.2 \mathrm{a}$ & $19.2 \mathrm{a}$ & $19.2 \mathrm{a}$ & $19.5 \mathrm{a}$ & $19.1 \mathrm{a}$ & $23.2 \mathrm{ab}$ & $24.0 \mathrm{~b}$ & $22.5 \mathrm{a}$ \\
\hline Maximum T & $29.7 \mathrm{ab}$ & $31.1 \mathrm{~b}$ & $29.6 \mathrm{a}$ & $26.4 \mathrm{a}$ & $27.1 \mathrm{a}$ & $25.9 \mathrm{a}$ & $29.6 \mathrm{a}$ & $31.1 \mathrm{~b}$ & $29.3 \mathrm{a}$ \\
\hline Minimum T & $17.7 \mathrm{a}$ & $18.6 \mathrm{a}$ & $17.7 \mathrm{a}$ & $13.7 \mathrm{a}$ & $14.0 \mathrm{a}$ & $13.7 \mathrm{a}$ & $17.4 \mathrm{a}$ & $18.3 \mathrm{a}$ & $17.0 \mathrm{a}$ \\
\hline Average RH & $75.6 \mathrm{ab}$ & $72.2 \mathrm{a}$ & $77.1 \mathrm{~b}$ & $87.2 \mathrm{a}$ & $85.8 \mathrm{a}$ & $88.2 \mathrm{a}$ & $74.4 \mathrm{a}$ & $73.4 \mathrm{a}$ & $76.5 \mathrm{a}$ \\
\hline Maximum RH & $99.1 \mathrm{a}$ & $98.7 \mathrm{a}$ & $99.6 \mathrm{a}$ & $100.0 \mathrm{a}$ & $100.0 \mathrm{a}$ & $100.0 \mathrm{a}$ & $97.5 \mathrm{a}$ & $97.4 \mathrm{a}$ & $97.7 \mathrm{a}$ \\
\hline Minimum RH & $41.7 \mathrm{~b}$ & $37.3 \mathrm{a}$ & $48.0 \mathrm{c}$ & $60.7 \mathrm{a}$ & $58.6 \mathrm{a}$ & $65.7 \mathrm{~b}$ & $44.3 \mathrm{a}$ & $43.2 \mathrm{a}$ & $49.4 \mathrm{~b}$ \\
\hline
\end{tabular}

For each period separately, averages followed by different letters in the same line differ statistically from each other $(\mathrm{P}<0.05)$

conditions in relation to minimum $\mathrm{RH}$, which was due to the increase in the inside maximum temperatures. Guiselini and Sentelhas (2004) observed that the minimum RH during the daytime period was influenced by the plastic covers, because during the day the saturation water vapor pressure (es) inside the greenhouses reached values above those observed outside, which resulted in a lower RH, even with an increase of actual vapor pressure (ea) caused by the retention of water vapor by the plastic cover (Buriol et al., 2000; Furlan, 2001; Viana, 2000).

The daily variation of average air temperature $\left({ }^{\circ} \mathrm{C}\right)$ over the three tomato growing seasons showed very similar results, except for days from $9 / 19 / 08$ to $9 / 23 / 08$ in the $1^{\text {st }}$ period, in which the outside average temperatures were far below to those observed inside the greenhouses. From this atypical period, two days were selected for evaluating hourly air temperature (Figure 5). It was observed that from 8:00 am to 4:00 pm occurred the largest differences between the outside and inside temperatures, reaching a maximum of $3.0^{\circ} \mathrm{C}$ in EI (plastic anti-UV + thermo-reflective screen) and $5.7^{\circ} \mathrm{C}$ in EII (diffusive plastic). In a cloudy sky day, the difference between the outside and inside temperatures decreased with a maximum of $2.7^{\circ} \mathrm{C}$ in $\mathrm{EI}$ (plastic anti-UV + thermo-reflective screen) and $4.2^{\circ} \mathrm{C}$ in EII (diffusive plastic) at 9:00 am. During overcast days, when the solar radiation is lower, differences between inside and outside temperatures is also lower, which is consistent with the results presented by Pandorfi (2006), which showed that under this condition air temperature inside greenhouses remain close to the outside.

Table 5 presents the relationship between outside and inside temperatures of each studied environment. The angular coefficients of the equations are always very close to one, which leads to the conclusion that air temperature inside the greenhouses were very similar to outside during all periods, with a maximum difference of around 7\%. Pandorfi (2006) analyzing the angular coefficients of the relationship between outside
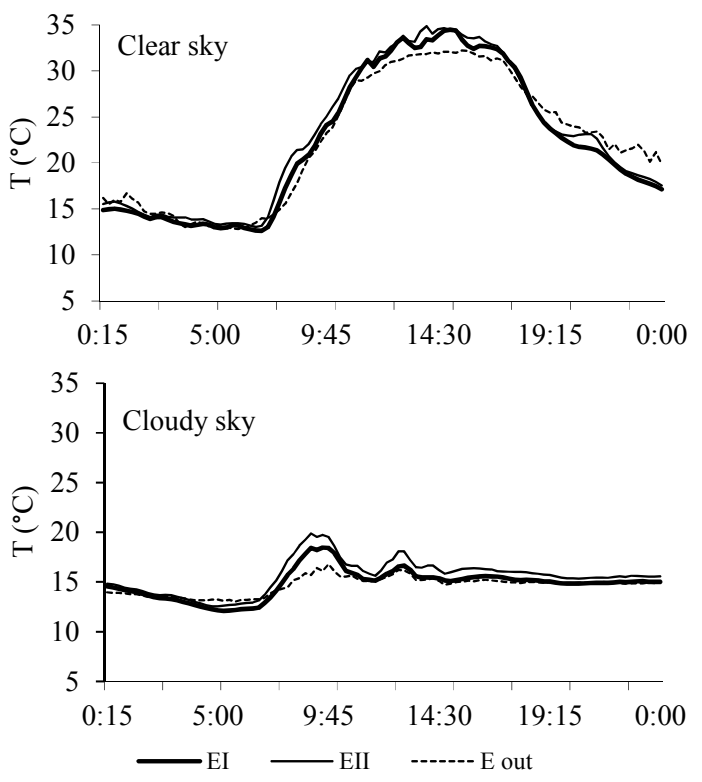

Figure 5 - Hourly average air temperature every 15 minutes during days of clear sky (9/19/08) and cloudy sky (9/21/08) conditions in the $1^{\text {st }}$ period, being: Environment I $(\mathrm{EI})=$ polyethylene anti-UV + thermoreflective screen; Environment II (EII) = diffusive plastic screen and outside conditions (E out).

and inside temperatures with thermo-reflective screen installed internally found increases of about $7 \%$. Table 5 also presents the relationship between outside and inside RH. According to the magnitude of the angular coefficients of the linear equations for each environment and period, the RH inside greenhouses were always lower than outside, with the largest differences occurring in EII (diffusive plastic), due to its higher temperatures.

It is possible to observe that the tomato productivity (Table 6) were significantly different between the environments. In the environment II, tomato plants were more productive than those grown under environment I. The excessive shading in the environment I, caused by the plastic anti-UV associated to 
the thermo-reflective screen, influenced negatively the tomato plants productivity.

Table 5 - Relationship between air temperature $(\mathrm{T})$ and relative humidity $(\mathrm{RH})$ observed inside Environment I $(\mathrm{EI})=$ polyethylene anti-UV + thermo-reflective screen; Environment II (EII) = diffusive plastic screen; and outside (E out) the greenhouses.

\begin{tabular}{|c|c|c|c|}
\hline \multirow{2}{*}{ Period } & \multirow{2}{*}{ Linear regression } & \multicolumn{2}{|c|}{ Coefficients } \\
\hline & & $\mathrm{b}$ & $\mathrm{R}^{2}$ \\
\hline \multicolumn{4}{|c|}{$\mathrm{T}\left({ }^{\circ} \mathrm{C}\right)$} \\
\hline \multirow{2}{*}{$1^{\mathrm{st}}$} & EI $x$ E out & 10.106 & 0.7526 \\
\hline & EII $x$ E out & 10.597 & 0.7033 \\
\hline \multirow{2}{*}{$2^{\text {nd }}$} & EI $x$ E out & 10.054 & 0.9737 \\
\hline & EII $x$ E out & 10.241 & 0.9476 \\
\hline \multirow{2}{*}{$3^{\mathrm{rd}}$} & EI $x$ E out & 10.316 & 0.8920 \\
\hline & EII $x$ E out & 10.681 & 0.9523 \\
\hline \multicolumn{4}{|c|}{ RH $(\%)$} \\
\hline \multirow{2}{*}{$1^{\text {st }}$} & EI $x$ E out & 0.9789 & 0.9712 \\
\hline & EII $x$ E out & 0.9369 & 0.9685 \\
\hline \multirow{2}{*}{$2^{\text {nd }}$} & EI $x$ E out & 0.9871 & 0.9451 \\
\hline & EII $x$ E out & 0.9724 & 0.9554 \\
\hline \multirow{2}{*}{$3^{\mathrm{rd}}$} & EI $x$ E out & 0.9734 & 0.9951 \\
\hline & EII $x$ E out & 0.9604 & 0.9942 \\
\hline
\end{tabular}

\section{CONCLUSION}

The available solar energy in the greenhouse covered with diffusive plastic was greater than those obtained under the anti-UV film with thermo-reflective screen. The same pattern was observed for PAR and Rn in all of the evaluated periods. Despite this fact, the values of temperature and relative humidity inside the greenhouse covered with diffusive plastic were very similar to outside conditions, reaching small differences, on average, $1.8^{\circ} \mathrm{C}$ above the outside temperature and $4.4 \%$ lower than external RH. The diffusive plastic promoted a higher cherry tomato productivity, for the three periods evaluated when compared to the anti-UV film with thermo-reflective screen. Based on that, the main conclusion of this study is that the use of diffusive plastic screen in greenhouses can be recommended to regions where high temperatures occur, since it provides a better inside distribution of solar energy without causing major changes in air temperature and relative humidity, resulting in higher tomato productivity.

\section{ACKNOWLEDGEMENTS}

The authors are grateful to 'Polysack Plastic Industries Ltda' for supplying the shading screens and to 'São Paulo Research Foundation - FAPESP' for supporting this project (Process $n^{\circ}:$ 2008/58624-1) and the first author with a master scholarship (Process nº: 2007/57897-1).
Table 6 - Average productivity of tomato plants in each studied environment, in three periods, being: Environment $\mathrm{I}(\mathrm{EI})=$ polyethylene anti-UV + thermo-reflective screen and Environment II (EII) = diffusive plastic screen.

\begin{tabular}{ccccc}
\hline Period & & Prod. $\left(\mathrm{kg} \mathrm{pl}^{-1}\right)$ & $\mathrm{CV}(\%)$ & $\mathrm{R}^{2}$ \\
\hline $1^{\text {st }}$ & EII & $5.11 \mathrm{a}$ & 22.18 & 0.606 \\
& EI & $3.41 \mathrm{~b}$ & & \\
\hline $2^{\text {nd }}$ & EII & $4.33 \mathrm{a}$ & 7.26 & 0.910 \\
& EI & $3.06 \mathrm{~b}$ & & \\
\hline $3^{\text {rd }}$ & EII & $4.79 \mathrm{a}$ & 5.21 & 0.932 \\
& EI & $3.25 \mathrm{~b}$ & & \\
\hline
\end{tabular}

* For each period separately, averages followed by different letters in the same column differ statistically from each other $(\mathrm{P}<0.05)$.

\section{REFERENCES}

BAILLE, A.; LÓPEZ, J.C.; CABRERA, J.; GONZALEZREAL, M.M.; PÉREZ-PARRA, J. Characterization of the solar diffuse component under "parral"type greenhouses. Acta Horticulturae, Leuven, n. 614, p. 341-346, 2003. BURIOL, G.A.; RIGHI, E.Z.; SCHNEIDER, F.M.; STRECK, N.A.; HELDWEIN, A.B.; ESTEFANEL, V. Modificação da umidade relativa do ar pelo uso e manejo da estufa plástica. Revista Brasileira de Agrometeorologia, Santa Maria, v. 8, n. 1, p. 11-18, 2000.

CALIMAN, F.R.B.; SILVA, D.J.H.; FONTES, P.C.R.; STRINGHETA, P.C.; MOREIRA, G.R.; CARDOSO, A. A. Avaliação de genótipos de tomateiro cultivados em ambiente protegido e em campo nas condicoes edafoclimaticas de Vicosa. Horticultura Brasileira, Brasilia, v. 23, n. 2, p. 255-259, 2005.

CASTILLA, N. Invernaderos de plástico: tecnologia y manejo. Madrid: Mundi-Prensa, 2005. 462 p.

FARIA JUNIOR, M.J.A.; SOUZA, R.A.R. de; HORA, R.C. da. Cultivo de alface em ambiente protegido, sob diferentes níveis de sombreamento, em duas épocas de plantio. Horticultura Brasileira, Brasília, v. 18, p. 232-233, 2000.

FINCH, D.A.; BAILEY, W.G.; MCARTHUR, L.J.B.; NASITWITWI, M. Photosynthetically active radiation regimes in a southern African savanna environment. Agricultural and Forest Meteorology, Amsterdam, v. 122, p. 229-238, 2004.

FRISINA, V.A.; ESCOBEDO, J.F. Balanço de radiação e energia da cultura de alface em estufa de polietileno. Pesquisa Agropecuária Brasileira, Brasília, v. 34, n. 10, p. 1775-1786, 1999.

FURLAN. R.A. Avaliação da nebulização e abertura de cortinas na redução da temperatura do ar em ambientes protegidos. 2001. 146 p. Tese (Doutorado em Irrigação 
e Drenagem) - Escola Superior de Agricultura "Luiz de Queiroz”, Universidade de São Paulo, Piracicaba, 2001.

GALVANI, E. Avaliação agrometeorológica do cultivo de pepino (Cucumis sativus I.) em ambiente protegido e a campo, em períodos de outono-inverno e primaveraverão. 2001. 124 p. Tese (Doutorado em Energia na Agricultura) - Faculdade de Ciências Agronômicas, Universidade Estadual Paulista "Julio Mesquita Filho", Botucatu, 2001.

GUISELINI, C. Microclima e produção de gérbera em ambientes protegidos com diferentes tipos de cobertura. 2002. 53 p. Dissertação (Mestrado em Física do Ambiente Agrícola) - Escola Superior de Agricultura "Luiz de Queiroz”, Universidade de São Paulo, Piracicaba, 2002.

GUISELINI, C.; SENTELHAS, P.C. Uso de malhas de sombreamento em ambiente protegido I: efeito na temperatura e na umidade do ar. Revista Brasileira de Agrometeorologia, Santa Maria, v. 12, n. 1, p. 9-17, 2004.

GUISELINI, C.; SENTELHAS, P.C.; PANDORFI, H.; HOLCMAN, E. Temperatura e umidade do ar em ambientes protegidos cobertos com plástico transparente associado à malha termo-refletora, instalada externa e internamente. Revista Brasileira de Agrometeorologia, v.15, p.157-162. 2007.

KITTAS, C.; BAILlE, A.; GIAGLARAS, P. Influence of covering material and shading on the spectral distribution of light in greenhouse. Journal of Agricultural Engineering Research, London, v. 73, p. 341-51, 1999.

PANDORFI, C.G. Manejo de cobertura de ambientes protegidos: alterações micrometeorológicas e efeitos na produção e na qualidade de gérbera. 2006. 95 p. Tese (Doutorado em Física do Ambiente Agrícola) - Escola Superior de Agricultura "Luiz de Queiroz", Universidade de São Paulo, Piracicaba, 2006.

PEZZOPANE, J.E.M.; OLIVEIRA, P.C. de; REIS, E.F. dos; LIMA; J.S.S. Alterações microclimáticas causadas pelo uso de tela plástica. Engenharia Agrícola, Jaboticabal, v. 24, n. 1, p. 9-15, jan./abr. 2004.
ROCHA, R.C. Uso de diferentes telas de sombreamento no cultivo protegido do tomateiro. 2007. 105 p. Tese (Doutorado em Irrigação e Drenagem) - Faculdade de Ciências Agronômicas, Universidade Estadual Paulista "Julio Mesquita Filho", Botucatu, 2007.

SENTELHAS, P.C.; BORSATTO, R.S.; MINAMI, K. Transmissividade da radiação solar em estufas cobertas com filmes de PVC azul e transparente. Revista Brasileira de Agrometeorologia, Santa Maria, v. 7, n. 2, p. 157-162, 1999.

SENTELHAS, P.C.; VILLA NOVA, N.A.; ANGELOCCI, L.R. Efeito de diferentes tipos de cobertura em miniestufas na atenuação da radiação solar e da luminosidade. In: CONGRESSO BRASILEIRO DE AGrometeOrologia, 10., 1997, Piracicaba. Anais... Piracicaba: Sociedade Brasileira de Agrometeorologia, 1997. p. 479-481.

SERRANO, T.D.; GUZMÁN, E.E.; RECIO, A.F.; GARCÍA, J.C.J.; GÁLVEZ, J.L.; CANO, A.S. Los filmes plásticos en la producción agrícola. Madrid: Mundi-Prensa, 2001. $320 \mathrm{p}$.

SHIRAHIGI, F.H. Produtividade e qualidade de híbridos de tomate (Solanum lycopersicum L.) dos segmentos Santa Cruz e Italiano em função do raleio de frutos, em ambiente protegido. 2009. 80p. Dissertação (Mestre em Fitotecnia) - Escola Superior de Agricultura "Luiz de Queiroz”, Universidade de São Paulo, Piracicaba, 2009.

STEIDLE NETO, A.J.; RIBEIRO, A.; ZOLNIER, S.; LEITE, F.P. Variabilidade sazonal da relação entre a radiação fotossinteticamente ativa e a radiação global na Bacia do Rio Doce, Estado de Minas Gerais. Acta Scientiarum Agronomy, Maringá, v. 28, n. 3, p. 427-31, 2006.

VIANA, T.V.A. Evapotranspiração obtida com o sistema razão de bowen e um lisímetro de pesagem em ambiente protegido. 2000. 98 p. Tese (Doutorado em Agronomia) - Escola Superior de Agricultura "Luiz de Queiroz", Universidade de São Paulo, Piracicaba, 2000. 